\title{
An analysis of manual and autoanalysis for submicrosecond parameters in the typical first lightning return stroke
}

\author{
Muhammad Akmal Bahari' ${ }^{1}$, Zikri Abadi Baharudin², Tole Sutikno ${ }^{3}$, Ahmad Idil Abdul Rahman ${ }^{4}$ \\ Mohd Ariff Mat Hanafiah ${ }^{5}$, Mazree Ibrahim ${ }^{6}$ \\ ${ }^{1}$ Faculty of Electrical Engineering, Universiti Teknikal Malaysia Melaka, 76100 Durian Tunggal, Melaka, Malaysia \\ ${ }^{2,4,5,6}$ Faculty of Engineering Technology, Kampus Teknologi, Universiti Teknikal Malaysia Melaka, Malaysia \\ ${ }^{3}$ Department of Electrical Engineering, Universitas Ahmad Dahlan, Yogyakarta, Indonesia
}

\section{Article Info}

Article history:

Received Apr 27, 2021

Revised Jul 15, 2021

Accepted Jul 27, 2021

\section{Keywords:}

Autoanalysis

Feature extraction

Lightning detection system

Return stroke

Submicrosecond

\begin{abstract}
The mechanism on how lightning detection system (LDS) operated never been exposed by manufacturer since it was confidential. This scenario motivated the authors to explore the issue above by using MATLAB to develop autoanalysis software based on the feature extraction. This extraction is intended for recognizing the parameters in the first return stroke, and compare the measurement between the autoanalysis software and the manual analysis. This paper is a modification based on a previous work regarding autoanalysis of zero-crossing time and initial peak of return stroke using features extraction programming technique. Further, the parameter on rising time of initial peak is added in this autoanalysis programming technique. Finally, the manual analysis using WaveStudio (LeCroy product) of those two lightning parameters is compared with autoanalysis software. This study found that the autoanalysis produce similar result with the manual analysis, hence proved the reliability of this software.
\end{abstract}

This is an open access article under the CC BY-SA license.

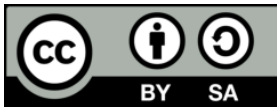

\section{Corresponding Author:}

Zikri Abadi Baharudin

Department of Electrical and Electronic Engineering Technology

Faculty of Engineering Technology, Universiti Teknikal Malaysia Melaka

Fakulti Teknologi Kejuruteraan Elektrik dan Elektronik (FTKEE), Kampus Teknologi

Universiti Teknikal Malaysia Melaka, Hang Tuah Jaya, 76100 Durian Tunggal, Melaka, Malaysia

Email: zikri@utem.edu.my

\section{INTRODUCTION}

Lightning has been an interesting phenomenon to discover by researcher and power engineer. It was begun from the work of Benjamin Franklin until recently, many investigations reveal the mysteries behind this phenomenon. The lightning is immense electrical energy which occurs less than a second [1]-[3]. There are thousands of amperes released when the lightning struck [4]-[7]. Overvoltage due to lightning will cause insulation to burn if the power equipment is not protected, and as a result, the power system will completely shut down [8]-[12]. The lightning brought damages towards electrical appliance and electrical distribution power system [7], [13]-[21].

The investigation and reports by many researchers showed that the characteristics of electric fields generated by lightning flashes using a single station measurement with high resolutions of 12 bits transient recorder and recording with several nanoseconds accuracy, was considered as a ground truth measurement [19], [22]-[24] where the technique allowed one to distinguish between the ICs' activities and the preceding process of ground flashes [4], [22], [23]. Presented a progress of studies towards the understanding of the possible effects of lightning to the various objects, particularly for a sensitive electronic device. Thus, various 
type of lightning location systems was built in such a way that the electric field from the lightning strike can be located and characterize the lightning paramaters for advancing this particular research work. The investigation outcome helps an electrical engineer for designing the electrical protection and determine the potential of the equipment to withstand the effect of lightning [5], [11], [18], [19], [21], [24]-[27].

Four types of geolocation techniques, known as time of arrival, direction, optical imagery and combined special techniques were discussed in [28], [29]. Lightning geolocations techniques used multiple sensors for measuring the time of the particular characteristic of a lightning event electromagnetic wave form. Furthermore, at least four sensors were required, as well as the determination of its time, latitude, and longitude [30], [31]. Sensors in the long-range lightning finding system could measure the propagation of the lightning electromagnetic influenced by Earth-ionosphere waveguide over thousands of kilometres [32], [33]. This strategy is based on the notion that lightning very low frequency (VLF) waves propagate through the ionosphere with dispersion, causing higher frequency components to arrive before lower frequency components, as mentioned in [32], [34], [35]. Second, magnetic direction finding (MDF) is used for VLF range, whereas broadband interferometry is used for very high frequency (VHF) range. In [36] used VLF interferometry in the study to improve direction finding accuracy, while [33] and [37] used VHF interferometry. MDF is defined as a technique that employs two orthogonal loop antennas to measure the magnetic field waveform produced by a lightning event [38]. Explained that the azimuth of a lightning event could be calculated by measuring each loop.

Generally, a combination of direction vector (MDF) and sensor location allow one to locate lightning location based on the peak proportion amplitude of the electromagnetic waveform produced by an illumination event. Simultaneously intercepted vectors from two or more sensors identify an event site with lightning [24]. In addition, MDF can be employed when two or more sensors simultaneously intercept can calculate the time, latitude and longitude of a flash event. Two or more three-axis magnetic field sensors are required to determine the altitude for a lightning event [39], [40]. Each sensor needs to have three orthogonal loop antennas to calculate the altitude and the capability to measure the azimuth and elevation angles of a reported lightning event [38]. VHF interferometry is another method to find direction [41]. A lightning system that uses sensors that have been built into a variety of antennas. Like the MDF technique, lightning event location measurements were conducted simultaneously with two or more sensors to determine the location of the lightning event. An azimuth information is provided by the derivation of the time of arrival (phases difference) from the VHF signals associated with the lightning events among individual sensor antennas. The measurement utilizing magnetic direction finding, on the other hand, suffers from local site inaccuracies. To acquire absolute angle estimation, these errors must be taken into account. As the distance from the detector grows, the constant angle error becomes more linear. Using at least three sensors with sensor direction vectors intersecting at a right angle is the simplest way to reduce constant angle error.

Thirdly, an optical imaging is a satellite-based lightning detection technology that uses the radiation emitted by clouds to geolocate photographs captured from space [39], [42]-[45]. The cloud top could measure cloud-to-ground and intracloud lightning flashes [46], [47]. Optical imaging can also be used to establish time, latitude, and longitude. Optical imaging cannot, however, be utilized to determine the altitude of a lightning strike's site. The fourth lightning locating system employs a variety of techniques, including integrated and unique ones. Combining time of arrival and magnetic direction finding, or broadband VHF interferometry and optical imaging, are two examples of integrated approaches. The time of arrival and magnetic direction-finding techniques were used together for the first time to build a lightning locating system. When employing the combined methodology given by [29], more sensors are required to establish the geolocation of a lightning incident. Furthermore, broadband VHF interferometry and optical imaging were used in the second combined and unique methodology. According to [48], [49], in the low-earth orbiting satellite-based lightning locating system, a two antennas system was employed to predict a direction of arrival together with optical imagery to geolocate a lightning occurrence. The benefit of using this strategy was that it reduced local site error. The position of a lightning strike event can be obtained more accurate and reliable [50], [51].

There are four different types of lightning locating systems. Arrival time, direction finding, optical imaging, and combination and special procedures are all available. The three forms of stand-alone lightning locating systems are time of arrival, direction finding, and optical imaging. In comparison to stand-alone lightning locating systems, the combined and customized methodologies provided a more reliable lightning locating system. Although there are several lightning locating systems in the world, the lightning analysis system is inadequate. When analyzing lightning data, all of the systems rely on manual measurement [52], [53].

This research compares the analysis between the manual analysis of WaveStudio software provided by LeCroy and the autoanalysis software that based on features extraction technique. This study is aimed to discover the reliability of the autoanalysis programming for determining the lightning parameters: (i) duration of the zerocrossing and (ii) the duration of the rising time. This study is a modification of previous work by [24], [39] 
regarding on autoanalysis of first return stroke based zero-crossing time of the initial peak using features extraction programming technique. Furthermore, in this paper the parameter of rising time for the initial peak of the first return stroke is added in this autoanalysis programming technique. Finally, the manual analysis (using LeCroy WaveStudio) of those two lightning parameters is compared with autoanalysis programmed of submicrosecond parameters based on typical first return stroke waveshape. The contribution of this research is useful for initial development towards the automation of the lightning location system.

\section{METHOD}

In this study, the 32 typical lightning data were analysed. The data of the lightning obtained from the measurement setup consist of the parallel-plate antenna, buffer circuit and the oscilloscope. The typical lightning analysed by using two methods. The first method was using manual measurement. The second method was by using the programming method. The programmed software to measure the duration of the lightning zero-crossing and the duration of the rising time was built. The algorithm in the programmed software was tested to ensure the measurement was reliable. The autoanalysis software as shown in Figure 1 was tested by running several iterations with many. The threshold value of zero crossing which were based on well-known lightning parameters were chosen ranging from 35 to $70 \mu \mathrm{s}$. According to the autoanalysis software of Figure 1, the most accurate threshold volume was $40 \mu \mathrm{s}$. This study chose $40 \mu \mathrm{s}$ as the appropriate threshold value to utilise in the algorithm to measure the duration of the zero-crossing in the first return stroke to avoid false detection [22], [23].

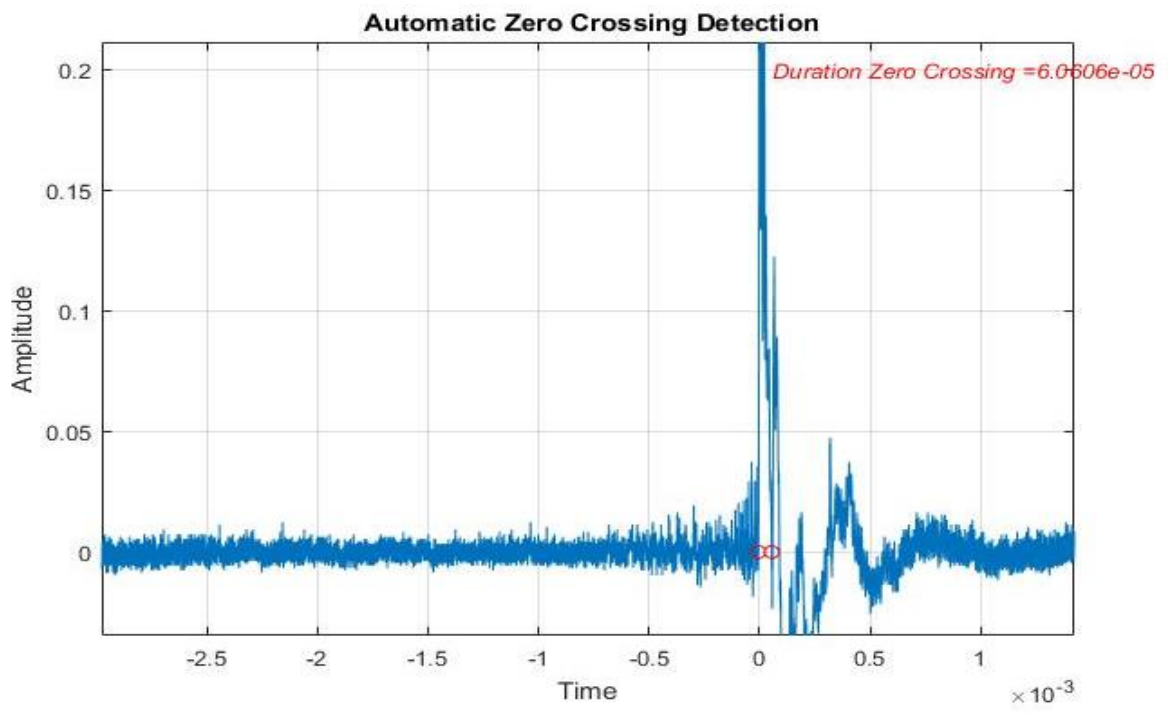

Figure 1. Autoanalysis software determine the duration of the zero-crossing under MATLAB platform

The (1) shows a part of the algorithm involves in this research. The t0 (k-1) is the time of the amplitude at the end of the zero-crossing time duration while the to $(\mathrm{k})$ is the time of the amplitudes at the start of the zero-crossing duration. The value of 0.00004 is the threshold value of $40 \mu$ s for the zero-crossing detection [22], [23].

$$
t 0(k-1)-t 0(k)>0.00004
$$

The (2) used for rising time detection. This research uses this equation in the algorithm to find the rising time of the first return strokes. The ynorm variable it a variable which contain information about the value of the sample amplitudes. If the samples amplitudes reach more than 0.5 the samples are marked as a potential first return stroke amplitude. The sample of time is 210 was used to simplify the detection processes of the rising time. The algorithm ignores all the first 210 samples to ensure accurate first return stroke could be detected. Finally, this study suggested that a value of 0.5 is the minimum value to recognise the first return stroke.

$$
\text { ynorm }(k+210)>0.5
$$




\section{RESULTS AND DISCUSSION}

The statistical of autoanalysis based on 32 of selective samples from typical ground flashes are examined in this study. Next, the results of autoanalysis are compared with the manual analysis results. The manual analysis was performed by using WaveStudio under Teledyne LeCroy product (Version 9.0.0.1). Table 1 indicates that the results from both methods are identical to each other. On one hand the results of autoanalysis software are reliable. Referring to the geometric mean and arithmetic mean of zero crossing between the manual analysis and autoanalysis, the discrepancy is too small with approximately $1.28 \%$ and $1.24 \%$, respectively. Further, the different of geometric mean and arithmetic mean of rising time duration between the manual analysis and autoanalysis is $8 \%$ and $12.9 \%$, respectively, which can be considered as small discrepancy and acceptable.

From previous study in [40], [46], [47], [50] manual analysis results are tabulate in Table 2. Next, the comparison results between the autoanalysis and manual analysis are validated using the arithmetic mean of zero crossing. The different of autoanalysis compared the works of [40], [46], [47], [50] found to be under a factor of 1.26, 1.32, 1.37 and 1.2, respectively. Therefore, it appears there is no different between the results. According to [40], [53] the duration of the zero-crossing rises as a result of the increased current moment and charges to be neutralized in the initial return stroke in a lightning event. All the researchers mentioned in Table 2 used same measurement technique known as accurate-stroke-count that based on measurements based on the correlated electric field recording on the electric fields generated by the whole flash with high levels of temporal resolution [4].

Next, the result of rising time of autoanalysis is compared with work of the researchers as mention in Table 3 from various locations. Similarly, as carried out in the analysis above, the comparison is based on the arithmetic mean of rising time. The different of autoanalysis compare the works of [40], [48], [50] found to be under a factor of 1.20, 1.06, and 1.8, respectively. The autoanalysis result is similar with of [40], [48]. On the other hand, autoanalysis result is slightly different compared to the previous study [50]. Even if we compare the results of this work (either manual or software) and [40] it appears a slightly different between the results. We suggest that the different may due to the different of geographical region and the latitude effect.

Table 1. The comparison between an autoanalysis software and manual analysis

\begin{tabular}{ccccc}
\hline \multirow{2}{*}{ Means } & \multicolumn{2}{c}{ Rising Time } & \multicolumn{2}{c}{ Zero Crossing } \\
& Manual $(\mu \mathrm{s})$ & Software $(\mu \mathrm{s})$ & Manual $(\mu \mathrm{s})$ & Software $(\mu \mathrm{s})$ \\
\hline Geometric & 5.0 & 4.6 & 62.3 & 63.1 \\
Arithmetic & 5.4 & 4.7 & 64.1 & 64.9 \\
\hline
\end{tabular}

Table 2. The comparison from various locations with autoanalysis for the duration of the zero-crossing

\begin{tabular}{ccc}
\hline Researcher & Location & Zero Crossing Time $(\mu \mathrm{s})$ \\
\hline Lin [50] & Florida & 54.0 \\
Cooray [46] & Sweden & 49.0 \\
Haddad [47] & Florida & 89.0 \\
Wooi [40] & Malaysia & 50.7 \\
This study -manual & Malaysia & 64.1 \\
This study -software & Malaysia & 64.9 \\
\hline
\end{tabular}

Table 3. The comparison between autoanalysis and manual analysis for the duration of the rising time

\begin{tabular}{cccc}
\hline Researcher & Location & Year & 10-90\% Rise Time $(\mu \mathrm{s})$ \\
\hline Lin [50] & Florida & 1979 & 2.6 \\
Rakov and Uman [38] & General & 2003 & 5.0 \\
Wooi [40] & Malaysia & 2016 & 3.9 \\
This research/study - Software & Malaysia & 2020 & 4.7 \\
This research/study - Manual & Malaysia & 2020 & 5.4 \\
\hline
\end{tabular}

Based on the comparison, it was found that the arithmetic methods using autoanalysis software for the combination of fast transition and zero time crossing parameters detection in this study is appropriate and reliable since the determination of the autoanalysis software is comparable with the manual analysis. It will be interesting and enhance more understanding on auto-analysis study if one can consider this type of analysis by considering the uncommon lightning mechanism such as attempted leader as reported by [23], [54] while, common lightning flashes such as reported by [19], [24], [55], [56]. For future works, the technique of time-frequency distributions (TFDs) analysis for detection and classification of the lightning return stroke will be explored since this technique can solve a big sample and complexity of the variety of the parameters [13], [16], [52], [57]. 


\section{CONCLUSION}

This study was conducted to compare the manual analysis and the autoanalysis operated by the software based on well-known lightning parameters (zero crossing and rising time duration). The results from the comparison have found remarkably with similar result with each other. Hence proved that the accuracy of the software is reliable. However, the equation in the algorithm cannot detect the zero-crossing duration less than $40 \mu \mathrm{s}$. In future, research should be carried out on the case of zero crossing less than $40 \mu \mathrm{s}$. Further, the analysis work should also consider the case of final stepped leader pulse that associated on the abrupt of the initial first return stroke because the effect of this pulse may alter the zero-crossing pulse.

\section{ACKNOWLEDGMENT}

The authors would like to thank all staff in Fakulti Teknologi Kejuruteraan Elektrik \& Elektronik, and CRIM in UTeM for their facilities, support and cooperation during our measurement campaign. This work fully utilized the equipments from the funding by Ministry of Education Malaysia (MOE) under ERGS/2013/FKE/TK02/UTEM/03/01 and FRGS/2/2014/TK03/FTK/03/F00248.

\section{REFERENCES}

[1] A. H. Khavari, A. Munir, and Z. Abdul-Malek, "Circuit-based method for extracting the resistive leakage current of metal oxide surge arrester," Bull. Electr. Eng. Informatics, vol. 9, no. 6, pp. 2213-2221, 2020, doi: 10.11591/eei.v9i6.2258.

[2] M. F. Yaakub, M. A. M. Radzi, F. H. M. Noh, and M. Azri, "Silicon carbide power device characteristics, applications and challenges: An overview," Int. J. Power Electron. Drive Syst., vol. 11, no. 4, pp. 2194-2202, 2020, doi: 10.11591/ijpeds.v11.i4.pp2194-2202.

[3] A. Thabet and Y. Mobarak, "Innovative earthing systems for electric power substations using conductive nanoparticles,” Int. J. Electr. Comput. Eng., vol. 11, no. 3, pp. 1857-1864, 2021, doi: 10.11591/ijece.v11i3.pp18571864.

[4] Z. A. Baharudin, "Characterizations of ground flashes from tropic to northern region," (Doctoral dissertation, Acta Universitatis Upsaliensis), 2014.

[5] A. M. Yusof "Lightning generated electric field over land and sea at Northern Region of Peninsular Malaysia: Measuring Setup," Indones. J. Electr. Eng. Informatics, vol. 8, no. 3, pp. 457-464, 2020, doi: 10.11591/ijeei.v8i3.1273.

[6] N. A. Ahmad, M. R. Mohd Esa, Z. Zakaria, Z. Adzis, and M. A. Bakar Sidik, "Wavelet analysis of narrow bipolar pulses in tropical region," in 2017 International Conference on Electrical Engineering and Computer Science (ICECOS), 2017, pp. 280-284, doi: 10.1109/ICECOS.2017.8167150.

[7] I. Ullah, M. N. R. Baharom, H. Ahmad, H. M. Luqman, and Z. Zainal, "Electric filed intensity of the lightning strikes on lightning air terminals installed on building structures," Int. J. Electr. Comput. Eng., vol. 7, no. 6, pp. 3105-3113, 2017, doi: 10.11591/ijece.v7i6.pp3105-3113.

[8] M. Z. R. M. Z. R. Zuber Ahmadi, A. Jidin, K. B. K. B. Jaffar, M. N. M. N. Othman, and R. N. P. R. N. P. Nagarajan, "Minimization of torque ripple utilizing by 3-L CHMI in DTC," Proc. 2013 IEEE 7th Int. Power Eng. Optim. Conf. PEOCO 2013, no. June, pp. 636-640, 2013, doi: 10.1109/PEOCO.2013.6564625.

[9] L. R. Raj, A. Jidin, C. W. Wan, M. Zalani, K. A. Karim, W. Y. Goh, and M. H. Jopri, "Improved performance of DTC of five-phase induction machines," 2013 IEEE 7th International Power Engineering and Optimization Conference (PEOCO), pp. 613-618, 2013, doi: 10.1109/PEOCO.2013.6564621.

[10] A. Zahari, H. Zainuddin, M. S. Kamarudin, N. F. Ambo, J. M. Wari, and I. S. Chairul, "Development of test vessel for gas insulation breakdown test," Int. J. Power Electron. Drive Syst., vol. 9, no. 2, pp. 873-879, 2018, doi: 10.11591/ijpeds.v9n2.pp873-879.

[11] D. C. Phan, "Reduction of the number of faults caused by lightning for transmission line," Int. J. Electr. Comput. Eng., vol. 9, no. 5, pp. 3366-3374, 2019, doi: 10.11591/ijece.v9i5.pp3366-3374.

[12] Wijono, Z. Abidin, W. Djuriatno, E. Maulana, and N. Ribath, "Design of 4-stage Marx generator using gas discharge tube,” Bull. Electr. Eng. Informatics, vol. 10, no. 1, pp. 55-61, 2021, doi: 10.11591/eei.v10i1.1949.

[13] A. R. R. Abdullah, N. S. S. Ahmad, N. Bahari, M. Manap, A. Jidin, and M. H. Jopri, "Short-circuit switches fault analysis of voltage source inverter using spectrogram," Electr. Mach. Syst. (ICEMS), 2013 Int. Conf., pp. 18081813, 2013, doi: 10.1109/icems.2013.6713294.

[14] A. F. Noor Azam et al., "Current control of BLDC drives for EV application," 2013 IEEE 7th International Power Engineering and Optimization Conference (PEOCO), pp. 411-416, 2013, doi: 10.1109/PEOCO.2013.6564583.

[15] L. R. L. Victor, A. Jidin, K. A. Karim, T. Sutikno, and R. Sundram, "Improved torque control performance of direct torque control for 5-phase induction machine," Int. J. Power Electron. Drive Syst., vol. 3, no. 4, p. 391, 2013, doi: 10.11591/ijpeds.v3i4.5249.

[16] M. F. B. F. Habban, M. Manap, M. H. H. Jopri, A. R. R. Abdullah, M. H. H. Jopri, and T. Sutikno, "An Evaluation of linear time frequency distribution Analysis for VSI switch faults identification," Int. J. Power Electron. Drive Syst., vol. 8, no. 1, p. 1, 2017, doi: 10.11591/ijpeds.v8i1.pp1-9.

[17] O. K. Kareem, A. I. Adekitan, and A. Awelewa, "Power distribution system fault monitoring device for supply networks in Nigeria," Int. J. Electr. Comput. Eng., vol. 9, no. 4, pp. 2803-2812, 2019, doi: 10.11591/ijece.v9i4.pp2803-2812. 
[18] J. Perko, S. Nikolovski, and L. Majdandžić, "Comparative analysis of power quality indices for different lighting techniogies in public lightning," Int. J. Electr. Comput. Eng., vol. 8, no. 2, pp. 880-887, 2018, doi: 10.11591/ijece.v8i2.pp880-887.

[19] T. H. Kuan, K. W. Chew, and K. H. Chua, "Behavioral studies of surge protection components," Bull. Electr. Eng. Informatics, vol. 10, no. 1, pp. 10-22, 2020, doi: 10.11591/eei.v10i1.2665.

[20] M. Z. Hussin, S. F. A. Shukor, N. D. M. Sin, Y. Yusof, M. Z. M. Nor, and N. H. A. Rahman, "Integration of LEDbased lighting in academic buildings for energy efficiency considerations," Bull. Electr. Eng. Informatics, vol. 10, no. 1, pp. 93-100, 2021, doi: 10.11591/eei.v10i1.2513.

[21] A. Bendakir, A. Bayadi, and D. Dib, "Towards the prospection of an optimal thermal response of zno surge arrester in hv power system," Int. J. Electr. Comput. Eng., vol. 11, no. 3, pp. 1865-1875, 2021, doi: 10.11591/ijece.v11i3.pp1865-1875.

[22] Z. A. Baharudin, V. Cooray, M. Rahman, P. Hettiarachchi, and N. A. Ahmad, "On the characteristics of positive lightning ground flashes in Sweden," J. Atmos. Solar-Terrestrial Phys., vol. 138-139, pp. 106-111, 2016, doi: 10.1016/j.jastp.2015.12.014.

[23] P. N. S. Ab Rahman, Z. A. Bharudin, and N. H. A. Rahim, "Misidentification of type of lightning flashes in Malaysia," TELKOMNIKA (Telecommunication Computing Electronics and Control), vol. 12, no. 8, pp. 59385945, 2014, doi: 10.11591/telkomnika.v12i8.6269.

[24] A. I. A. Rahman, M. A. Bahari, Z. A. Baharudin, A. A. Zulkefle, M. Zainon, and M. A. M. Hanafiah, "Sub Microsecond Analysis of Negative Cloud-to-Ground Lightning Flashes," Indones. J. Electr. Eng. Comput. Sci., vol. 11, no. 2, pp. 711-717, 2018, doi: 10.11591/ijeecs.v11.i2.pp711-717.

[25] N. M. Kassim, M. Manap, N. A. Ngatiman, and M. R. Yusoff, "Localization of Multiple Harmonic Sources for Inverter Loads Utilizing Periodogram,” J. Teknol., vol. 8, no. 2, pp. 87-91, 2016.

[26] M. Jopri, A. Abdullah, T. Sutikno, and M. Manap, "A Utilisation of Improved Gabor Transform for Harmonic Signals Detection and Classification Analysis," Int. J., vol. 7, no. 1, pp. 21-28, 2017, doi: 10.11591/ijece.v7i1.pp21-28.

[27] C.-L. Wooi, Z. Abul-Malek, M. N. K. Hafizi Rohani, A. M. B. Yusof, S. N. M. Arshad, and A. I. Elgayar, "Comparison of lightning return stroke channel-base current models with measured lightning current," Bull. Electr. Eng. Informatics, vol. 8, no. 4, pp. 1478-1488, 2019, doi: 10.11591/eei.v8i4.1613.

[28] A. Nag, M. J. Murphy, W. Schulz, and K. L. Cummins, "Lightning locating systems: Insights on characteristics and validation techniques," Earth Sp. Sci., vol. 2, no. 4, pp. 65-93, 2015, doi: 10.1002/2014EA000051.

[29] R. L. Dowden, J. B. Brundell, and C. J. Rodger, "VLF lightning location by time of group arrival (TOGA) at multiple sites,” J. Atmos. Solar-Terrestrial Phys., vol. 64, no. 7, pp. 817-830, 2002, doi: 10.1016/S1364-6826(02)00085-8.

[30] K. L. Cummins and M. J. Murphy, "An overview of lightning locating systems: History, techniques, and data uses, with an in-depth look at the US NLDN," IEEE Trans. Electromagn. Compat., vol. 51, no. 3, pp. 499-518, 2009, doi: 10.1109/TEMC.2009.2023450.

[31] A. Gulyás, "Application of preventive measures in lightning protection,” 2011.

[32] M. Ozaki, S. Yagitani, K. Miyazaki, and I. Nagano, "An improved distance finding technique for single-site lightning location system using reflection characteristics of the anisotropic ionosphere," in 2011 XXXth URSI General Assembly and Scientific Symposium, 2011, pp. 1-4.

[33] J.-Y. Lojou and K. L. Cummins, "Total lightning mapping using both VHF interferometry and time-of-arrival techniques," in International Conference on Lightning Protection, Kanazawa, Japan, 2006, pp. 391-396.

[34] E. T. Pierce, "Latitudinal variation of lightning parameters," J. Appl. Meteorol., vol. 9, no. 1, pp. 194-195, 1970, doi: 10.1175/1520-0450(1970)009<0194:LVOLP>2.0.CO;2.

[35] A. Chilingarian, Y. Khanikyants, E. Mareev, D. Pokhsraryan, V. A. Rakov, and S. Soghomonyan, "Types of lightning discharges that abruptly terminate enhanced fluxes of energetic radiation and particles observed at ground level,” J. Geophys. Res. Atmos., vol. 122, no. 14, pp. 7582-7599, 2017, doi: 10.1002/2017JD026744.

[36] R. Ismail and Z. A. Baharudin, "A review on basic principle of lightning location in multi-station system and the ability of single-station measurement," in 2016 IEEE International Conference on Power and Energy (PECon), 2016, pp. 62-67, doi: 10.1109/PECON.2016.7951534.

[37] P. R. Krehbiel, H. E. Edens, Michael Stock, W. Rison, and Manabu Akita, "Continuous broadband digital interferometry of lightning using a generalized cross-correlation algorithm," J. Geophys. Res. Atmos., vol. 119, no. 6, pp. 3134-3165, 2014, doi: 10.1002/2013JD020217.

[38] A. F. Munauwer, Z. A. Baharudin, M. A. M. Hanafiah, M. Zainon, S. N. S. Salim, and M. Ibrahim, "Unravel the extent of the existence of positive ground flash in Malaysia," Int. J. Emerg. Trends Eng. Res., vol. 8, no. 11.1 Special Issue, pp. 166-169, 2020, doi: 10.30534/ijeter/2020/2681.12020.

[39] A. I. Abd Rahman, M. A. Bahari, and Z. A. Baharudin, "Investigation of Zero Crossing Detection for First Return Stroke in Negative Cloud-to-Ground Lightning Flash," Int. J. Integr. Eng., vol. 11, no. 3, 2019, doi: 10.30880/ijie.2019.11.03.031.

[40] C.-L. Wooi, Z. Abdul-Malek, N.-A. Ahmad, and A. I. El Gayar, "Statistical analysis of electric field parameters for negative lightning in Malaysia," J. Atmos. Solar-Terrestrial Phys., vol. 146, pp. 69-80, 2016, doi: 10.1016/j.jastp.2016.05.007.

[41] N. A. Lafta and S. S. Hreshee, "Wireless sensor network's localization based on multiple signal classification algorithm," Int. J. Electr. Comput. Eng., vol. 11, no. 1, pp. 498-507, 2021, doi: 10.11591/ijece.v11i1.pp498-507.

[42] A. I. A. Rahman, M. A. Bahari, and Z. A. Baharudin, "Investigation of Zero Crossing Detection for First Return Stroke in Negative Cloud-to-Ground Lightning Flash,” Int. J. Integr. Eng, vol. 11, no. 3, 2019, doi: 10.30880/ijie.2019.11.03.031. 
[43] A. Nag and V. A. Rakov, "Pulse trains that are characteristic of preliminary breakdown in cloud-to-ground lightning but are not followed by return stroke pulses," J. Geophys. Res. Atmos., vol. 113, no. 1, pp. 1-12, 2008, doi: 10.1029/2007JD008489.

[44] H. Chenina, D. Benatia, and M. Boulakroune, "New modeling approach of laser communication in constellation and through atmospheric disturbances," Bull. Electr. Eng. Informatics, vol. 10, no. 4, pp. 2088-2099, 2021, doi: 10.11591/EEI.V10I4.2792.

[45] H. L. Chua and A. Huong, "Photoacoustic technology for biological tissues characterization," Bull. Electr. Eng. Informatics, vol. 9, no. 6, pp. 2601-2608, 2020, doi: 10.11591/eei.v9i6.2624.

[46] V. Cooray and S. Lundquist, "On the characteristics of some radiation fields from lightning and their possible origin in positive ground flashes," J. Geophys. Res., vol. 87, no. C13, p. 11203, 1982, doi: 10.1029/jc087ic13p11203.

[47] M. A. Haddad, V. A. Rakov, and S. A. Cummer, "New measurements of lightning electric fields in Florida: Waveform characteristics, interaction with the ionosphere, and peak current estimates," J. Geophys. Res. Atmos., vol. 117, no. D10, 2012, doi: 10.1029/2011JD017196.

[48] V. A. Rakov, J. He, D. Wang, and P. K. Wang, "Lightning: physics and effects," Cambridge university press, 2003, doi: 10.1016/j.atmosres.2013.05.005.

[49] J. R. Dwyer and M. A. Uman, "The physics of lightning," Phys. Rep., vol. 534, no. 4, pp. 147-241, 2014, doi: 10.1016/j.physrep.2013.09.004.

[50] M. A. Uman, R. D. Brantley, Y. T. Lin, J. A. Tiller, and W. H. Beasley "Characterization of lightning return stroke electric and magnetic fields from simultaneous two-station measurements,” J. Geophys. Res. Ocean., vol. 84, no. C10, pp. 6307-6314, 1979, doi: 10.1029/JC084iC10p06307.

[51] A. Sunjerga, M. Rubinstein, F. Rachidi, and V. Cooray, "On the Initiation of Upward Negative Lightning by Nearby Lightning Activity: An Analytical Approach,” J. Geophys. Res. Atmos., vol. 126, no. 5, p. e2020JD034043, 2021, doi: 10.1029/2020JD034043.

[52] M. R. Ab. Ghani et al., "A Critical Review of Time-frequency Distribution Analysis for Detection and Classification of Harmonic Signal in Power Distribution System.," Int. J. Electr. Comput. Eng., vol. 8, no. 6, pp. 4603-4618, 2018, doi: 10.11591/ijece.v8i6.pp.4603-4618.

[53] S. N. M. Arshad et al., "Characterization Preliminary Breakdown in the Measured Lightning Electric Fields on Malaysia Data," in Applied Mechanics and Materials, 2015, vol. 793, pp. 19-23, doi: 10.1109/PEOCO.2014.6814468.

[54] N. Asyiqin "On the Existence of Attempted Leader in Tropical Thunderstorm," vol. 8, pp. 153-157, 2020, doi: 10.30534/ijeter/2020/2481.12020.

[55] V. A. Rakov and M. A. Uman, "Some properties of negative cloud-to-ground lightning flashes versus stroke order," J. Geophys. Res. Atmos., vol. 95, no. D5, pp. 5447-5453, 1990, doi: 10.1029/JD095iD05p05447.

[56] P. N. S. A. Rahman, Z. A. Bharudin, and N. H. A. Rahim, "Misidentification of type of lightning flashes in Malaysia," TELKOMNIKA (Telecommunication Computing Electronics and Control), vol. 12, no. 8, pp. 59385945, 2014, doi: 10.11591/telkomnika.v12i8.6269.

[57] M. H. Jopri, A. R. Abdullah, T. Sutikno, M. Manap, and M.R. Yusoff, "An improved detection and classification technique of harmonic signals in power distribution by utilizing spectrogram," Int. J. Electr. Comput. Eng., vol. 7, no. 1, p. 12, 2017, doi: 10.11591/ijece.v7i1.pp12-20. 